Check for updates

Cite this: RSC Adv., 2017, 7, 42826

\title{
Protective effects of canolol against hydrogen peroxide-induced oxidative stress in AGS cells
}

\author{
Ling Han, Xiaoyang Xia, Xia Xiang, (D) Fenghong Huang* and Zhen Zhang
}

Oxidative stress, as mediated by ROS, plays a critical role during the occurrence and development of chronic diseases. Canolol is a phenolic compound recently isolated from crude canola oil with powerful antioxidative properties. In this paper, the effects of canolol on hydrogen peroxide $\left(\mathrm{H}_{2} \mathrm{O}_{2}\right)$-induced oxidative stress in AGS cells were investigated. Cell viability experiments showed negligible cytotoxicity of canolol to AGS cells within a dose of $100 \mu \mathrm{M}$. Additionally, it was found that canolol could effectively prevent the oxidative injury caused by $\mathrm{H}_{2} \mathrm{O}_{2}$. The pretreatment of AGS cells by canolol also resulted in a reduction in ROS and MDA levels, and LDH release. The survival of cells and the activities of superoxide dismutase (SOD), glutathione peroxidase (GSH) and catalase (CAT) were significantly increased with the pre-incubation of AGS cells with canolol before $\mathrm{H}_{2} \mathrm{O}_{2}$ exposure. Consequently, apoptosis and loss of mitochondrial membrane potential of the AGS cells were alleviated, and $\mathrm{H}_{2} \mathrm{O}_{2}$-induced caspase-3 activation was inhibited. Therefore, it was concluded that canolol effectively protected AGS cells against $\mathrm{H}_{2} \mathrm{O}_{2}$-induced oxidative stress and its antioxidative effect was significant.

Received 2nd August 2017

Accepted 30th August 2017

DOI: $10.1039 / c 7 r a 08524 a$

rsc.li/rsc-advances

many human chronic diseases, including aging, diabetes, cardiovascular diseases and cancer. ${ }^{\mathbf{1 0 - 1 2}}$ Generally, the use of naturally occurring compounds with antioxidant activities is considered to be a promising approach to reduce oxidative stress. ${ }^{13,14}$ Therefore, the protective effect against oxidative stress has been successfully used to explore the potential nutritional values of food or natural products.

Gastric cancer is one of the major public health issue and the second leading cause of cancer death worldwide, which significantly impacts human's health. ${ }^{15,16}$ It is closely related to the change of oxidant-antioxidant status, causing the increase of cell proliferation, angiogenesis and apoptosis. ${ }^{17,18}$ However, the detailed functions of canolol in oxidative stress of gastric carcinoma cell have not yet been investigated. Human gastric adenocarcinoma cell line AGS has been widely used for studying the potential of compounds compared to human gastric epithelial cell line GES-1. ${ }^{19-22}$ Hydrogen peroxide $\left(\mathrm{H}_{2} \mathrm{O}_{2}\right)$ provides particularly important contributor to oxidative stress. ${ }^{23}$ Consequently, this study aimed to evaluate the role of canolol in modulating the oxidative stress of gastric carcinoma cell by treating AGS with hydrogen peroxide as a model. In addition, the protectively possible mechanisms were also explored by considering cytotoxicity and cell viability, intracellular ROS level, activities of antioxidant enzymes and protein, lipid peroxide level and apoptosis.

\section{Materials and methods}

Oil Crops Research Institute of the Chinese Academy of Agricultural Sciences, Oil Crops
and Lipids Process Technology National \& Local Joint Engineering Laboratory, Key Laboratory of Oilseeds Processing, Ministry of Agriculture, Hubei Key Laboratory of Lipid Chemistry and Nutrition, Key Laboratory of Biology and Genetic Improvement of Oil Crops, Ministry of Agriculture, Wuhan 430062, China. E-mail: xiangshi19850130@163.com; oiljgzx@gmail.com; Tel: +86-27-86711526

\subsection{Materials}

Ham's F-12K (Kaighn's) medium and fetal bovine serum (FBS) were obtained from Gibco (Life Technologies, Grand Island, 
NY). $\quad \mathrm{H}_{2} \mathrm{O}_{2}, \quad$ Trypsin, $\quad$ 3-(4,5-dimethylthiazol-2-yl)-2,5diphenyltetrazolium bromide (MTT), propidium iodide (PI), dimethyl sulfoxide (DMSO), Western blot reagents, and 2,7dichlorofluorescin diacetate (DCFH-DA) were purchased from Sigma-Aldrich Sigma (St. Louis, MO, USA). Lactate dehydrogenase (LDH), malondialdehyde (MDA), reduced glutathione (GSH), superoxide dismutase (SOD) and catalase (CAT) assay kits were obtained from Nanjing Jiancheng Bioengineering Institute (China). Annexin V-FITC Apoptosis Detection Kit was purchased from BD Biosciences (USA). Canolol was provided by our laboratory.

\subsection{Analysis of cell cytotoxicity and viability}

Cell culture. AGS cells were obtained from the American Type Culture Collection (ATCC; CRL-1739). AGS cells were cultured in $\mathrm{F}-12 \mathrm{~K}$ medium supplemented with $10 \%$ fetal bovine serum, at $5 \% \mathrm{CO}_{2}$ and $37{ }^{\circ} \mathrm{C}$, and the medium was changed every other day. When the AGS cells were about $90 \%$ confluent, cells were washed with PBS, detached with $0.25 \%$ trypsin EDTA, resuspended, and subcultured onto plates at an appropriate density according to each experimental scale.

Cell viability assay. Cell viability assay was measured using the MTT assay, which was based on the conversion of MTT to formazan crystals by mitochondrial dehydrogenases. Briefly, AGS cells were plated at density of $5 \times 10^{3}$ cells per well in 96well plates. After $24 \mathrm{~h}$ of incubation, canolol at different concentrations were added to the wells and incubated for $24 \mathrm{~h}$, and then the culture medium was replaced by $100 \mu \mathrm{L}$ of a solution of MTT. After $4 \mathrm{~h}$ of incubation at $37^{\circ} \mathrm{C}$, this solution was removed, and the produced formazan was solubilized in $150 \mu \mathrm{L}$ of DMSO. Absorbance was measured at $490 \mathrm{~nm}$ using a SpectraMax M2 microplate reader (Molecular Devices, Sunnyvale, CA). Cell viability was expressed as a percentage of the control culture value, which was considered as 100\% survival.

\subsection{Oxidative stress injury by $\mathrm{H}_{2} \mathrm{O}_{2}$}

AGS cells were seeded in culture plates with a density of about 5 $\times 10^{3}$ cells per well and incubated for $24 \mathrm{~h}$ before the experiment. AGS cells incubated in medium at $37{ }^{\circ} \mathrm{C}$ (control). Subsequently, the AGS cells were treated with $\mathrm{H}_{2} \mathrm{O}_{2}$ for another $4 \mathrm{~h}$. The supernate was removed and treated with $10 \mu \mathrm{L}$ of MTT (4 $\mathrm{mg} \mathrm{mL} \mathrm{mL}^{-1}$ final concentration in medium) for $4 \mathrm{~h}$. After removing supernate, $100 \mu \mathrm{L}$ of DMSO was added to dissolve the formed blue formazan crystals of live cells. The MTT measurement was the same as the described part of 2.2. The data were presented as the average standard deviation $(n=6)$.

\subsection{Measurement of intracellular reactive oxygen species} (ROS)

The ROS level was determined using DCFH-DA assay kit. DCFHDA was added to the cells and further oxidized to fluorescent 2,7-dichlorofluorescein (DCF) by ROS. In this work, AGS cells were incubated with canolol for $24 \mathrm{~h}$ and then treated by $\mathrm{H}_{2} \mathrm{O}_{2}$ for $4 \mathrm{~h}$. After washing the cells with PBS three times, DCFH-DA was added and incubated with cells for $30 \mathrm{~min}$ at $37^{\circ} \mathrm{C}$ in the dark. Then the cells were determined by on a microplate reader at the $E_{\mathrm{x}} / E_{\mathrm{m}}$ of 480 $\mathrm{nm} / 525 \mathrm{~nm}$ and flow cytometry (BD Biosciences, San Jose, CA).

\subsection{Cell apoptosis assay}

Annexin V-FITC/PI apoptosis detection kit was used to measure the apoptosis of AGS cells. Briefly, AGS cells were seeded in a 6-well culture plate and kept for overnight incubation at $37{ }^{\circ} \mathrm{C}$ in $5 \% \mathrm{CO}_{2}$. Then, cells were treated with different canolol concentrations $(5,50$, and $100 \mu \mathrm{M})$ for $24 \mathrm{~h}$, and then incubated with $\mathrm{H}_{2} \mathrm{O}_{2}$ for $4 \mathrm{~h}$. After incubation, cells were washed with PBS, harvested, and resuspended with binding buffer in tubes by Annexin-FITC and DAPI and kept at $4{ }^{\circ} \mathrm{C}$ for 20 min under dark conditions. Stained cells were analyzed using FACSCalibur ${ }^{\mathrm{TM}}$ Flow cytometry with Cell-Quest software.

\subsection{Measurements of LDH, MDA, GSH, SOD and CAT}

The assays for LDH, MDA, GSH, SOD and CAT were carried out using commercial kits (Beyotime Biotechnology Co. Ltd, Shanghai, China). The treated cells were harvested and sonicated at $4{ }^{\circ} \mathrm{C}$. The supernatants were collected for the analysis of LDH, MDA, SOD, GSH and CAT level by commercial kits following the manufacturer's instructions.

\subsection{Measurements of mitochondrial membrane potential}

The mitochondrial membrane potential was measured using JC-1 dye with flow cytometry. The treated AGS cells were collected, washed, and resuspended in $500 \mu \mathrm{L}$ PBS containing JC-1 solution at $37{ }^{\circ} \mathrm{C}$ for $20 \mathrm{~min}$. After centrifugation, the cells were resuspended twice in PBS and analyzed by flow cytometry.

\subsection{Assay of caspase assay}

The cell lysates of treated cells were extracted with lysis buffer containing 1\% Triton X-100, $50 \mathrm{mM} \mathrm{NaCl}, 50 \mathrm{mM} \mathrm{NaF}, 20 \mathrm{mM}$ Tris (pH 7.4), 1 mM EDTA, 1 mM EGTA, 1 mM sodium vanadate, $0.2 \mathrm{mM}$ PMSF, and $0.5 \%$ NP-40. An equal amount of cell lysate $(50 \mu \mathrm{g})$ was solubilized in sample buffer, boiled for $5 \mathrm{~min}$, and electrophoresed on a 4-20\% Tris-glycine gel (Invitrogen). Proteins were then transferred to polyvinylidine difluoride membrane (BioRad). Nonspecific binding was blocked with $20 \mathrm{mM}$ Tris- $\mathrm{HCl}$ buffered saline (pH 7.6) plus $0.05 \%$ Tween-20 (TBS-T) containing 5\% nonfat dry milk and $1 \%$ bovine serum albumin (BSA). After incubation with the appropriate primary antibody of caspase-3 (Cell Signaling), membranes were washed with TBS-T and then incubated with horseradish peroxidase antirabbit immunoglobulin $\mathrm{G}$ in the second reaction. Enhanced chemiluminescence reagent was used in accordance with the manufacturer's recommendations, and the resulting membranes were exposed to Kodak AR film and developed using a Kodak X-OM at processor.

\section{Results and discussions}

\subsection{Cell viability and ROS content of AGS cells injured with $\mathrm{H}_{2} \mathrm{O}_{2}$}

In order to accurately reflect the processing occurred in human body, a reliable in vitro cellular model was required. ${ }^{24}$ In this study, $\mathrm{H}_{2} \mathrm{O}_{2}$ was selected to induce injury on AGS cells for model construction. As shown in Fig. 1, with AGS cells exposed to 
increasing doses of $\mathrm{H}_{2} \mathrm{O}_{2}(60-1200 \mu \mathrm{M})$ for $4 \mathrm{~h}$, dose-dependent decreases from $100.00 \pm 0.93 \%$ to $46.45 \pm 0.82 \%$ in cell viability were found by MTT assays $(P<0.05)$. Meanwhile, the ROS contents were enhanced in dose-dependent manner with the increase of $\mathrm{H}_{2} \mathrm{O}_{2}$ dose because of the increase of cell death. At $400 \mu \mathrm{M}, \mathrm{H}_{2} \mathrm{O}_{2}$ caused an approximate $50 \%$ loss in cell viability and $40 \%$ enhancement in ROS content. Notably, at 100, 200 and $400 \mu \mathrm{M} \mathrm{H}_{2} \mathrm{O}_{2}$, the cell viability were $88.83 \pm 0.47 \%, 72.10 \pm$ $1.28 \%$ and $53.28 \pm 0.95 \%$, respectively, which showed that there were large changes in cell viability from 100 to $200 \mu \mathrm{M}$ and from 200 to $400 \mu \mathrm{M}$, which were approximate $17 \%$ and $19 \%$, respectively. Because different cell lines have certain difference in susceptibility to $\mathrm{H}_{2} \mathrm{O}_{2}$-induced cell death, the dosage of $200 \mu \mathrm{M}$ was used in our study to carry out the following experiments to obtain effective protection of canolol toward $\mathrm{H}_{2} \mathrm{O}_{2}$ induce cell death.

\subsection{Cytotoxicity and protective effects of canolol on AGS cells}

In the last few decades, numerous bioactive natural products with potential health benefits were widely used as sources for food-health fields. ${ }^{25}$ The cytotoxicity of these natural products was important for their use. The cytotoxicity of canolol was first studied. The structure of canolol is shown in Fig. 2a. MTT assay shown in Fig. 2b demonstrated that there were hardly changes in cell viability when AGS cells incubated with 50 and $100 \mu \mathrm{M}$ canolol. Significant decrease of cell viability was found with the increasing concentration of canolol from 200 to $1111 \mu \mathrm{M}$ compared to the control group. The results indicated that there was no toxicity to AGS cells at the concentration of $100 \mu \mathrm{M}$ used in this study. Then AGS cells were pre-treated with canolol over $24 \mathrm{~h}$ in different concentrations of canolol $(5,33,50,83$, $100 \mu \mathrm{M})$ before $\mathrm{H}_{2} \mathrm{O}_{2}$ incubation $(200 \mu \mathrm{M}$ for $4 \mathrm{~h})$. As shown in Fig. 2c, pretreatment with canolol prior to $\mathrm{H}_{2} \mathrm{O}_{2}$ exposure gradually enhanced the cell viability and decreased the ROS content of AGS cells with dose-dependent manner compared to solely $\mathrm{H}_{2} \mathrm{O}_{2}$-treated group $(P<0.05)$. Their cell viabilities were $71.39 \pm 1.64 \%\left(\mathrm{H}_{2} \mathrm{O}_{2}\right.$-treated group), $73.67 \pm 0.42 \%$

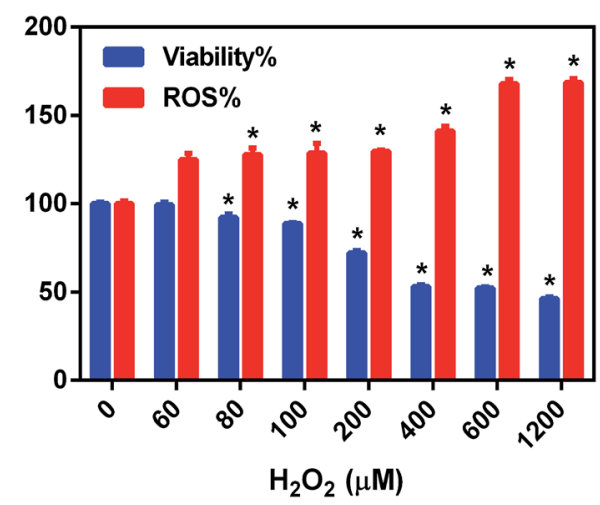

Fig. 1 The cell viability and $\mathrm{ROS}$ values in $\mathrm{H}_{2} \mathrm{O}_{2}$-injured AGS cells. The cells were treated with doses of $60-1200 \mu \mathrm{M}$ for $4 \mathrm{~h}$. The results were represented by mean $\pm \mathrm{SD}(n=3)$ from three independent experiments. Data was expressed as a percentage of the untreated control. The single asterisk indicated $P<0.05$ versus the control group.

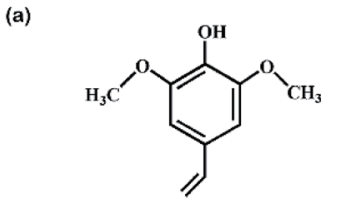

(b)
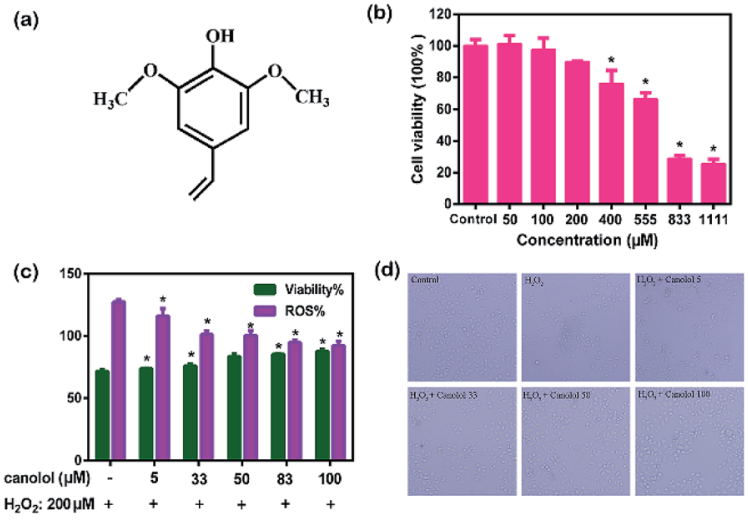

Fig. 2 (a) The structure of canolol. (b) The cytotoxicity of canolol on AGS cells. AGS cells incubated with different concentrations of canolol for $24 \mathrm{~h}$ by MTT assay. The curves shown in each graph were from a single experiment (mean $\pm \mathrm{SD}, n=6$ ). The single asterisk indicated $P<0.05$ versus the control group. (c) Effects of canolol on the cell viability and ROS content in AGS cells. The cells were pretreated with canolol $(5-100 \mu \mathrm{M})$ for $24 \mathrm{~h}$. The cell viability was determined by MTT assay. The ROS value was determined by ROS kits. The results were represented by mean \pm SD $(n=3)$ from three independent experiments. Data was expressed as a percentage of the untreated control. The single asterisk indicated $P<0.05$ versus the injury group. (d) Morphology of AGS cells exposed to $\mathrm{H}_{2} \mathrm{O}_{2}(200 \mu \mathrm{M})$ for $4 \mathrm{~h}$ with and without canolol pretreatment.

(5 $\mu \mathrm{M}$ canolol-treated group), $75.94 \pm 1.37 \%$ (33 $\mu \mathrm{M}$ canololtreated group), $83.27 \pm 2.47 \%$ (50 $\mu \mathrm{M}$ canolol-treated group), $85.34 \pm 0.41 \%$ (83 $\mu \mathrm{M}$ canolol-treated group), and $87.59 \pm$ $1.77 \%(100 \mu \mathrm{M}$ canolol-treated group). The ROS contents were $127.30 \pm 1.92 \%\left(\mathrm{H}_{2} \mathrm{O}_{2}\right.$-treated group), $116.02 \pm 5.88 \%$ ( $1 \mu \mathrm{M}$ canolol-treated group), $101.17 \pm 2.95 \%$ (33 $\mu \mathrm{M}$ canololtreated group), $100.41 \pm 3.88 \%$ (50 $\mu \mathrm{M}$ canolol-treated group), $94.63 \pm 1.18 \%$ (83 $\mu \mathrm{M}$ canolol-treated group), and $92.23 \pm$ $3.39 \%$ ( $100 \mu \mathrm{M}$ canolol-treated group). At the dose of $100 \mu \mathrm{M}$, the cell surviving was up to $90 \%$ whereas cell viability was about $70 \%$ without canolol treatment, revealing the prominent inhibition of canolol toward $\mathrm{H}_{2} \mathrm{O}_{2}$-induced cell death. Consistent with these results, the morphology of AGS cells exposure to $\mathrm{H}_{2} \mathrm{O}_{2}$ was obviously damaged compared to that of the control group (Fig. 2d). Pretreatment with canolol, the morphology of the cells were similar to that of the cells without $\mathrm{H}_{2} \mathrm{O}_{2}$. Meanwhile, the morphology of cells recovered better at high concentration of canolol than that at low dose, showing positive effects against $\mathrm{H}_{2} \mathrm{O}_{2}$-induce AGS cell injury.

\subsection{The inhibition of canolol on ROS production in AGS cells}

It has been reported that ROS production is closely related with cell damage and death, ${ }^{26}$ providing insights into the antioxidative activity of canolol. Therefore, the level of intracellular ROS was assessed in canolol-treated AGS cells by using $\mathrm{H}_{2}$ DCFDA, a fluorescent ROS indicator. As shown in Fig. 3, there were significant differences in the fluorescents signals of canolol pretreatment AGS cells. The mean fluorescence of ROS indicator was increased by about 1.5 fold in $\mathrm{H}_{2} \mathrm{O}_{2}$-treated AGS cells relative to the untreated control cells $(P<0.05)$. The signals for canolol pretreated groups were gradually decreased in dose- 
dependent manner $(P<0.05)$. At the canolol concentration of $100 \mu \mathrm{M}$, the fluorescent signal was greatly decreased to 1.2 fold compared to $\mathrm{H}_{2} \mathrm{O}_{2}$ injury group, which was close to the normal level without $\mathrm{H}_{2} \mathrm{O}_{2}$ treatment. The results showed that canolol could effectively protect the cells from intracellular ROS damage induced by $\mathrm{H}_{2} \mathrm{O}_{2}$. It has been reported that exogenous treatment with $\mathrm{H}_{2} \mathrm{O}_{2}$ could induce abnormal accumulation of intracellular ROS and the damage of cellular antioxidant defenses. ${ }^{27}$ Excess ROS caused protein and lipid oxidation as well as the destruction of nuclear DNA and mitochondrial integrity to ultimately induce cell death. The pre-treatment of cells with canolol could effectively eliminate these negative impacts by reducing the ROS levels.

Oxidative stress and ROS accumulation have been involved in many human chronic diseases, including aging, diabetes, cardiovascular diseases and cancer. In normal cell physiological process, the antioxidant system maintains the equilibrium between the generation and elimination of reactive oxygen species, whereas ROS levels dramatically increase under environmental stress, such as oxidative stress. ${ }^{28}$ Previous study reported that canolol treatment could obviously reduce the generation of ROS production of $t$-butyl hydroxide-damaged HEK-293 cells. ${ }^{5}$ Similarly, in the present study, canolol could remarkably diminish the ROS content generated by $\mathrm{H}_{2} \mathrm{O}_{2}$-induced oxidative stress in AGS cells.

\subsection{Effects of canolol on $\mathrm{H}_{2} \mathrm{O}_{2}$-induced apoptosis in AGS cells}

Excessive ROS readily results in damage of the biomolecules within the cell, ${ }^{29}$ causes proteins to denature and aggregate along with the collapse of the cell membrane, and eventually leads to cell apoptosis. ${ }^{30}$ Therefore, cell apoptosis is the major consequence for oxidation-induced change. In the present study, the anti-apoptosis effect of canolol on AGS cells was evaluated using the Annexin V-FITC/PI assay based on flow cytometry. In Fig. 4, the lower left quadrant represented normal cells. Cells in the lower right quadrant were considered as early apoptotic, and cells in the upper right quadrant were described as advanced apoptotic or necrotic. Compared to control group,
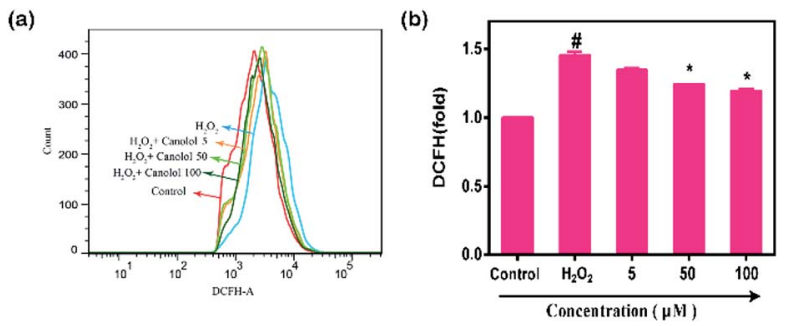

Fig. 3 The inhibition of canolol on $\mathrm{H}_{2} \mathrm{O}_{2}$-induced intracellular ROS production in AGS cells. (a) The intracellular ROS using $\mathrm{H}_{2}$ DCFDA by flow cytometric analysis. (b) The relative fluorescent intensity of ROS indicator compared to control group. The AGS cells were incubated with canolol for $24 \mathrm{~h}$, and then treated with $\mathrm{H}_{2} \mathrm{O}_{2}$ for $4 \mathrm{~h}$. The results were represented by a mean $\pm \mathrm{SD}(n=3)$. $\# P<0.05$ versus the control group. $* P<0.05$ versus $\mathrm{H}_{2} \mathrm{O}_{2}$-induced cells without canolol pretreatment.
$\mathrm{H}_{2} \mathrm{O}_{2}$-treated group increased the apoptosis percentage from $3.6 \%$ to $10.8 \%$, resulting in the fact that $\mathrm{H}_{2} \mathrm{O}_{2}$ diffused freely into and out of cells and tissues, destroying the intracellular environment, and ultimately leading to cell apoptosis. However, the apoptosis percentage gradually decreased in a dosedependent manner when the cells were pretreated by canolol before they were subjected to $\mathrm{H}_{2} \mathrm{O}_{2}$, which indicated that canolol provided a protection toward AGS cells against apoptosis caused by $\mathrm{H}_{2} \mathrm{O}_{2}$. Combination with the results of canolol toward the ROS production in AGS cells, the anti-apoptosis properties of canolol were related to ROS scavenging.

\subsection{The effect of canolol on the activities of biomolecules and enzymes levels in $\mathrm{H}_{2} \mathrm{O}_{2}$-injured AGS cells}

Due to the elimination of ROS was related to biomolecules and oxidant enzymes, ${ }^{31}$ the effects of canolol on the activities of biomolecules and enzymes levels in $\mathrm{H}_{2} \mathrm{O}_{2}$-injured AGS cells were investigated. As shown in Fig. 5a and b, after AGS cells were exposed to $\mathrm{H}_{2} \mathrm{O}_{2}$, the levels of $\mathrm{LDH}$ release and MDA were significantly increased compared to control group. Compared to $\mathrm{H}_{2} \mathrm{O}_{2}$-injured group, canolol-treated group significantly decreased the levels of LDH release and MDA, and displayed in dose-dependent manner with the increasing dose of canolol, suggesting that canolol prevented the damage of fragile cell membrane from $\mathrm{H}_{2} \mathrm{O}_{2}$, inhibiting the lipid peroxidation and reactive oxygen from pouring into the cells.

Meanwhile, $\mathrm{H}_{2} \mathrm{O}_{2}$-injured group obviously destroyed the activities and decreased the levels of GSH, SOD and CAT compared to the untreated group (Fig. 5c and e). With the pretreated AGS cells with canolol for $24 \mathrm{~h}$ and then incubation with $\mathrm{H}_{2} \mathrm{O}_{2}$, the levels of GSH, SOD and CAT were elevated in dose-dependent manner compared to injury group. The results clearly showed that canolol activated the intracellular antioxidant system, enhanced the expressions of antioxidant enzymes to protect AGS cells against $\mathrm{H}_{2} \mathrm{O}_{2}$-induced damage by scavenging intracellular ROS.

Lipid peroxidation is one of the primary events in free radical-mediated cell injury. MDA as a by-product of lipid peroxidation induced by excessive ROS is widely used as

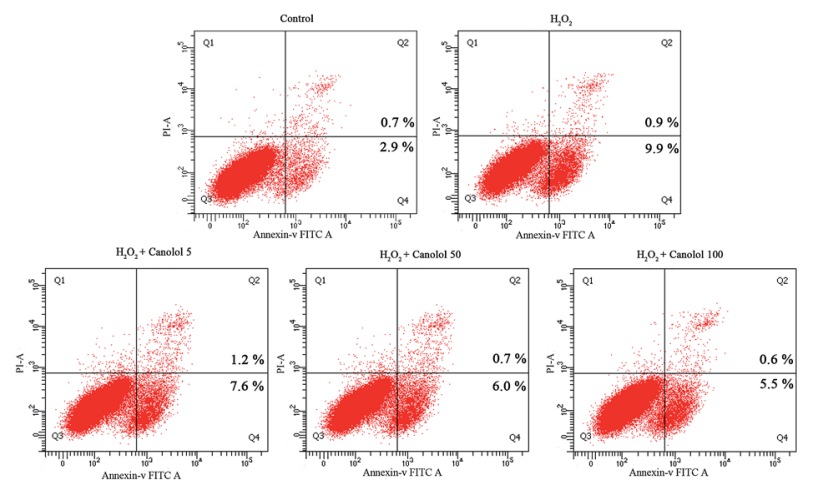

Fig. 4 Effects of canolol on $\mathrm{H}_{2} \mathrm{O}_{2}$-induced apoptosis in AGS cells. The AGS cells were preincubated with different concentrations of canolol $(5,50$ and $100 \mu \mathrm{M})$ for $24 \mathrm{~h}$ and then treated with $\mathrm{H}_{2} \mathrm{O}_{2}$ for $4 \mathrm{~h}$. 

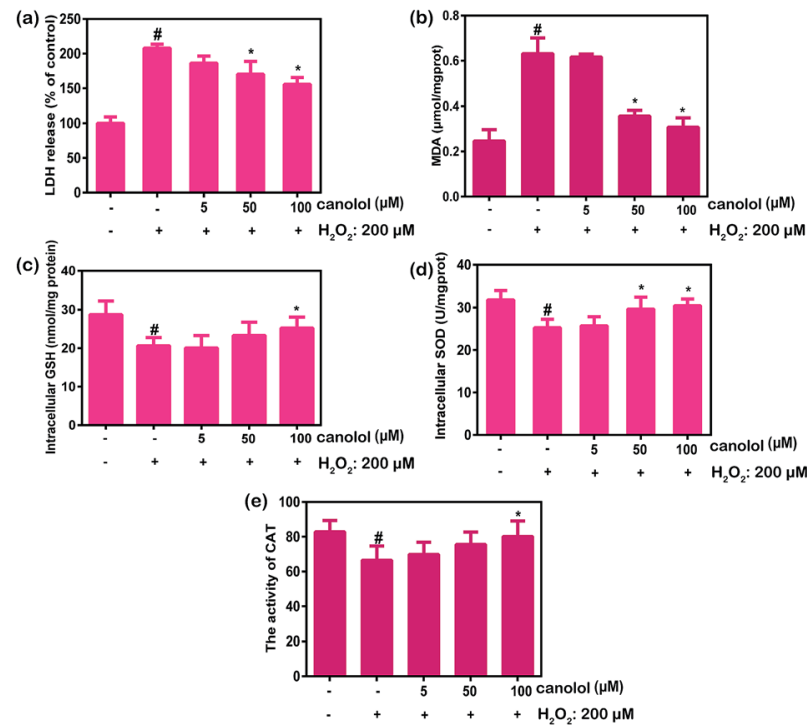

Fig. 5 The effect of canolol on the expression levels of LDH, MDA, GSH, SOD and CAT in $\mathrm{H}_{2} \mathrm{O}_{2}$-injured AGS cells. (a) Quantitative analysis of the value of $\mathrm{LDH}$ release level. (b) Quantitative analysis of the relative value of MDA. (c-e) Quantitative analysis of the values of GSH, SOD and CAT. The AGS cells were incubated with different concentrations of canolol for $24 \mathrm{~h}$ and then incubated with $\mathrm{H}_{2} \mathrm{O}_{2}$ for $4 \mathrm{~h}$, which were collected to detect the expression levels of oxidative-stress-related biomolecules and enzymes. The results were represented by a mean \pm $\mathrm{SD}(n=3)$. $\# P<0.05$ versus the control group. ${ }^{*} P<0.05$ versus $\mathrm{H}_{2} \mathrm{O}_{2}-$ induced cells without canolol pretreatment.

a biomarker of oxidative stress. ${ }^{32}$ In normal cell systems, there exists a balance level between generation of ROS and their elimination by intercellular antioxidant systems composed of some enzymes, such as SOD, GSH, and CAT. With the occurrence of stimuli, the balance is broken and generates excessive ROS, resulting in the lipid peroxidation. It has been reported that natural compounds trigger the detoxification enzymes that boost cellular defenses against oxidative stress. ${ }^{33}$ From the results, the modulation of SOD, GSH, and CAT activities by pretreatment with canolol compared to treatment with $\mathrm{H}_{2} \mathrm{O}_{2}$, indicates an ability of the cell defense system to respond to an oxidative insult.

\subsection{The effect of canolol on mitochondrial membrane potential $\left(\Delta \psi_{m}\right)$ in $\mathrm{H}_{2} \mathrm{O}_{2}$-injured AGS cells}

Mitochondrion plays a significant role in the apoptotic process, and the level of mitochondrial membrane potential $\left(\Delta \psi_{\mathrm{m}}\right)$ is considered to be an indicator of apoptosis. ${ }^{34} \mathrm{JC}-1$ dye and flow cytometric analysis were used to assess the change of $\Delta \psi_{\mathrm{m}}$ during apoptosis induced by $\mathrm{H}_{2} \mathrm{O}_{2}$ and protection of canolol in AGS cells. The decrease of red/green ratio indicated dissipation of the mitochondrial $\Delta \psi_{\mathrm{m}}$. As shown in Fig. 6, with $\mathrm{H}_{2} \mathrm{O}_{2}$ injured AGS cells, the red/green ratio decreased from $49.0 \%$ to $4.7 \%$, indicating that the $\mathrm{H}_{2} \mathrm{O}_{2}$ caused a depolarization in AGS cells. Pretreated with various concentration of canolol made the red/green ratio enhanced from $4.7 \%$ to $15.4 \%$ compared to $\mathrm{H}_{2} \mathrm{O}_{2}$ injury group, indicating that canolol partly suppressed the change by $\mathrm{H}_{2} \mathrm{O}_{2}$ to inhibit the apoptosis and necrosis.

\subsection{Effects of canolol on caspase-3 activation in $\mathrm{H}_{2} \mathrm{O}_{2}$ - injured AGS cells}

It has been widely reported that caspases are important mediators of apoptosis induced by various apoptotic stimuli. ${ }^{35}$ In order to explore the effects of canolol on apoptosis, the cleaved caspase-3 was investigated by western blotting analysis to examine the enzymatic activity of the caspase- 3 with respect to changes in protein expression. As shown in Fig. 7, $\mathrm{H}_{2} \mathrm{O}_{2}$-injured group significantly increased the activity of leaved caspase-3 (17 KD) compared to control group, which indicated that $\mathrm{H}_{2} \mathrm{O}_{2}$ activated caspase- 3 to induce apoptosis. However, canololtreated group attenuated the increase in cleaved caspase- 3 levels induced by $\mathrm{H}_{2} \mathrm{O}_{2}$ in AGS cells with dose-dependent manner, suggesting that canolol protected AGS cells against apoptosis by attenuation of caspase- 3 activation.

The relationship between oxidative stress and apoptosis has been widely explored. ${ }^{36,37}$ Current results confirmed that the anti-apoptosis properties of canolol were related to ROS scavenging. It has been reported that $\mathrm{H}_{2} \mathrm{O}_{2}$-induced cells exhibited high expression levels of caspase- 3 to cause cell apoptosis. ${ }^{38} \mathrm{Bai}$ and his co-workers reported that $\mathrm{D}$-limonene-treated group could inhibit the elevation of caspase-3 expression level compared with the $\mathrm{H}_{2} \mathrm{O}_{2}$-treated group in human lens epithelial cells. $^{39}$ Consistent with these results, our study also exhibited

(a)
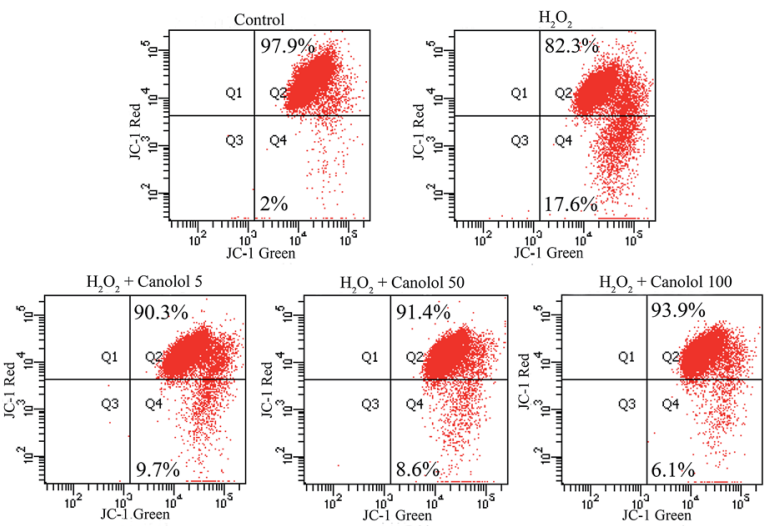

(b)

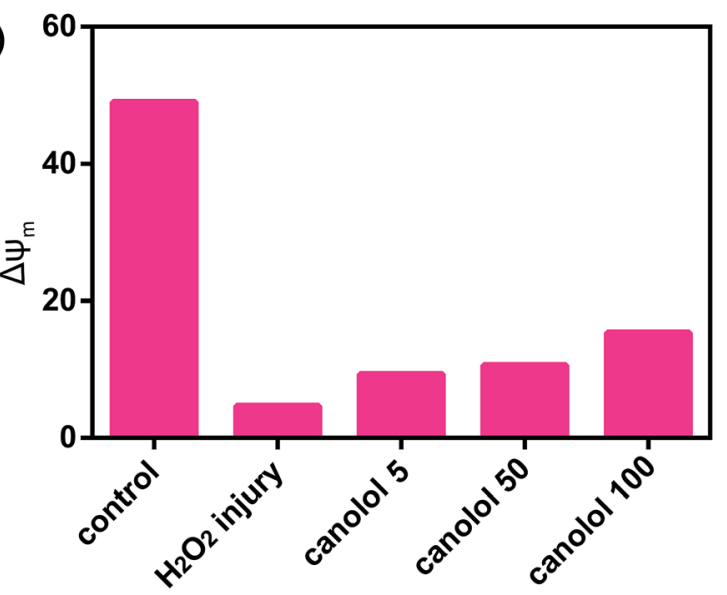

Fig. 6 Effects of canolol on $\Delta \psi_{m}$ in $\mathrm{H}_{2} \mathrm{O}_{2}$-injured AGS cells by JC-1 assay. (a) Flow cytometric analysis. (b) The values of red/green ratio. 


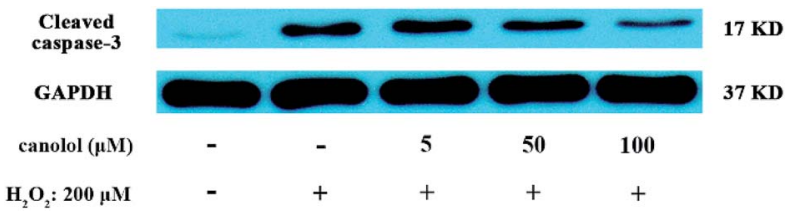

Fig. 7 Effects of canolol on the caspase- 3 activation in AGS cells. AGS cells were treated with canolol and then exposed to $\mathrm{H}_{2} \mathrm{O}_{2}$ for $4 \mathrm{~h}$. The density of caspase- 3 was determined.

that canolol-treated group similarly prevented the increase of caspase- 3 expression level compared with the $\mathrm{H}_{2} \mathrm{O}_{2}$-treated group. The short-term effect of canolol is mainly antiapoptotic. Bcl-2 family members play an important role in regulating apoptosis in $\mathrm{H}_{2} \mathrm{O}_{2}$-induced oxidative stress. These proteins are either antiapoptotic (e.g., Bcl-2, Bcl-XL, and Mcl-1) or proapoptotic (e.g., Bax, Bak, and Bad), and the interactions among them may influence cell fate. ${ }^{40}$ MAPKs pathways including ERK1/2, JNK1/2/3 and p38 MAPKs are also important regulators of apoptosis. ${ }^{41}$ It has been reported that Y-27632, a selective ROCK inhibitor could effectively inhibit $\mathrm{H}_{2} \mathrm{O}_{2}$-induced cell apoptosis by the inhibition of activated JNK1/2/3 and p38 MAPKs. Therefore, the antiapoptotic properties of canolol might also directly be related to the expression of Bcl-2 family members and MAPKs pathways. However, the exact mechanism underlying complexation response by canolol is still not fully understood. Thus it is necessary to investigate whether canolol has antioxidant effect by the above signal pathways in the future.

\section{Conclusions}

This study demonstrated that the cytotoxicity and protective effects of canolol toward $\mathrm{H}_{2} \mathrm{O}_{2}$-induced oxidative damage in AGS cells. MTT assays showed that there was no toxicity for canolol to AGS cells within the concentration of $100 \mu \mathrm{M}$. Canolol might protect $\mathrm{H}_{2} \mathrm{O}_{2}$-induced AGS cells death via attenuation of apoptosis and overproduction of ROS by its effect on redox system. A schematic model was designed to describe the cellular mechanism that canolol ameliorated ROS generation and apoptosis under $\mathrm{H}_{2} \mathrm{O}_{2}$ conditions in AGS cells. Briefly, canolol significantly inhibited ROS overproduction, mitochondrial damage, caspase activation and apoptosis in AGS cells response to $\mathrm{H}_{2} \mathrm{O}_{2}$ injury. Meanwhile, these effects of canolol were related to the increase of enzymatic activities and the decrease of $\mathrm{LDH}$ release and MDA levels. These findings suggested that this rapeseed polyphenol might be an important compound to be used in the development of new food agents for human health.

\section{Conflicts of interest}

There are no conflicts to declare.

\section{Acknowledgements}

This work was supported by the National Natural Science Foundation of China (31601438), the Agricultural Science and
Technology Innovation Project of Chinese Academy of Agricultural Sciences (CAAS-ASTIP-2013-OCRI), the Earmarked Fund for China Agriculture Research System (CARS-13) and the Director Fund of Oil Crops Research Institute (1610172016003).

\section{References}

1 K. Shrestha and B. D. Meulenaer, J. Agric. Food Chem., 2014, 62, 5412-5419.

2 K. Shrestha, C. V. Stevens and M. B. De, J. Agric. Food Chem., 2012, 60, 7506-7512.

3 C. Zheng, M. Yang, Q. Zhou, C. S. Liu and F. H. Huang, Eur. J. Lipid Sci. Technol., 2015, 116, 1675-1684.

4 D. Wakamatsu, S. Morimura, T. Sawa, K. Kida, C. Nakai and H. Maeda, Biosci., Biotechnol., Biochem., 2005, 69, 1568-1574. 5 X. Dong, Z. Li, W. Wang, W. Zhang, S. Liu, X. Zhang, J. Fang, H. Maeda and M. Matsukura, Mol. Vision, 2011, 17, 2040-2048. 6 X. Cao, T. Tsukamoto, T. Seki, H. Tanaka, S. Morimura, L. Cao, T. Mizoshita, H. Ban, T. Toyoda and H. Maeda, Int. J. Cancer, 2010, 122, 1445-1454.

7 N. Jallali, H. Ridha, C. Thrasivoulou, C. Underwood, P. E. Butler and T. Cowen, Osteoarthritis Cartilage, 2005, 13, 614-622.

8 Z. Z. Xie, Y. Liu and J. S. Bian, Oxid. Med. Cell. Longevity, 2016, 16, 6043038.

9 X. Qin, M. Cao, F. Lai, F. Yang, W. Ge, X. Zhang, S. Cheng, X. Sun, G. Qin and W. Shen, PLoS One, 2015, 10, e0127551.

10 D. F. Dai and P. S. Rabinovitch, Trends Cardiovasc. Med., 2009, 19, 213-220.

11 M. Dhanasekaran and J. Ren, Curr. Neurovasc. Res., 2005, 2, 447-459.

12 T. V. Fiorentino, A. Prioletta, P. Zuo and F. Folli, Curr. Pharm. Des., 2013, 19, 5695-5703.

13 V. L. Alfonso, B. Pedro, G. Francesca and J. L. Quiles, Antioxidants, 2015, 4, 447-481.

14 H. Kim, B. S. Park, K. G. Lee, C. Y. Choi, S. S. Jang, Y. H. Kim and S. E. Lee, J. Agric. Food Chem., 2005, 53, 8537-8541.

15 M. Orditura, G. Galizia, V. Sforza, V. Gambardella, A. Fabozzi, M. M. Laterza, F. Andreozzi, J. Ventriglia, B. Savastano and A. Mabilia, World J. Gastroenterol., 2014, 20, 1635-1649.

16 T. D. Sablet, M. B. Piazuelo, C. L. Shaffer, B. G. Schneider, M. Asim, R. Chaturvedi, L. E. Bravo, L. A. Sicinschi, A. G. Delgado and R. M. Mera, Gut, 2011, 60, 1189-1195.

17 P. Correa, G. Malcom, B. Schmidt, E. Fontham, B. Ruiz, J. C. Bravo, L. E. Bravo, G. Zarama and J. L. Realpe, Aliment. Pharmacol. Ther., 1998, 12, 73-82.

18 M. Serafini, R. Bellocco, A. Wolk and A. M. Ekström, Gastroenterology, 2002, 123, 985-991.

19 D. Kuck, B. Kolmerer, C. Ikingkonert, P. H. Krammer, W. Stremmel and J. Rudi, Infect. Immun., 2001, 69, 50805087.

20 M. T. Lin, C. Y. Juan, K. J. Chang, W. J. Chen and M. L. Kuo, Carcinogenesis, 2001, 22, 1947-1953.

21 H. Shirin, E. M. Sordillo, S. H. Oh, H. Yamamoto, T. Delohery, I. B. Weinstein and S. F. Moss, Cancer Res., 1999, 59, 2277-2281. 
22 H. Teng, Q. Huang and L. Chen, Food Funct., 2016, 7, 46054613.

23 Z. S. Xu, X. Y. Wang, D. M. Xiao, L. F. Hu, M. Lu, Z. Y. Wu and J. S. Bian, Free Radicals Biol. Med., 2011, 50, 1314-1323.

24 F. Cheli and A. Baldi, J. Food Sci., 2011, 76, R197-R205.

25 B. David, J. L. Wolfender and D. A. Dias, Phytochem. Rev., 2015, 14, 299-315.

26 P. Newsholme, E. P. Haber, S. M. Hirabara, E. L. Rebelato, J. Procopio, D. Morgan, H. C. Oliveira-Emilio, A. R. Carpinelli and R. Curi, J. Physiol., 2007, 583, 9-24.

27 R. S. Sohal and W. C. Orr, Free Radicals Biol. Med., 2012, 52, 539-555.

28 C. Liu, J. Hong, H. Yang, J. Wu, D. Ma, D. Li, D. Lin and R. Lai, Free Radicals Biol. Med., 2010, 48, 1173.

29 C. M. Quinzii, L. C. López, R. W. Gilkerson, B. Dorado, J. Coku, A. B. Naini, C. Lagier-Tourenne, M. Schuelke, L. Salviati and R. Carrozzo, FASEB J., 2010, 24, 3733-3743.

30 A. Srivastava, R. Harish and T. Shivanandappa, J. Agric. Food Chem., 2006, 54, 790-795.

31 S. A. Comhair and S. C. Erzurum, Am. J. Physiol.: Lung Cell. Mol. Physiol., 2002, 283, 246-255.
32 X. Lu, H. Guo and Y. Zhang, Int. J. Biol. Macromol., 2012, 50, 50-58.

33 Y. Kim, Y. Choi, H. Ham, H. S. Jeong and J. Lee, Food Chem., 2013, 137, 136-141.

34 M. Leist and M. Jäättelä, Nat. Rev. Mol. Cell Biol., 2001, 2, 589-598.

35 K. F. Tonissen, G. D. Trapani, S. J. Ralph and J. Neuzil, Mol. Nutr. Food Res., 2009, 53, 87-103.

36 M. G. Manuele, M. L. Barreiro Arcos, R. Davicino, G. Ferraro, G. Cremaschi and C. Anesini, Cancer Invest., 2010, 28, 135145.

37 D. Roberto, P. Micucci, T. Sebastian, F. Graciela and C. Anesini, Basic Clin. Pharmacol. Toxicol., 2010, 106, 38-44.

38 H. P. Yao, X. J. Tang, X. T. Shao, F. Lei, N. P. Wu and Y. Ke, Cell Res., 2007, 17, 565-571.

39 J. Bai, Y. Zheng, G. Wang and P. Liu, Oxid. Med. Cell. Longevity, 2016, 14, 1-12.

40 M. G. VanderHeiden, N. S. Chandel, E. K. Williamson, P. T. Schumacker and C. B. Thompson, Cell, 1997, 91, 627637.

41 X. Wang, B. Wang, Z. Li, G. Zhu, L. Heng, X. Zhu, Q. Yang, J. Ma and G. Gao, RSC Adv., 2016, 6, 49187-49197. 